\title{
PENGEMBANGAN VIDEO ANIMASI TERHADAP PENGETAHUAN KONSEP POLA ANAK USIA 5-6 TAHUN
}

\begin{abstract}
Abstrak
Penelitian ini dilakukan untuk menghasilkan produk berupa Video Animasi Terhadap Pengetahuan Konsep Pola Anak Usia 5-6 Tahun. Jenis penelitian ini adalah penelitian dan pengembangan (Research and Development).Hasil dari penelitian dan pengembangan ini mengacu pada langkah yang dikemukakan oleh Sugiyono (2016); 1) potensi dan masalah. 2) pengumpulan data dan informasi. 3) desain produk. 4) validasi produk; (a) uji ahli materi; (b) uji ahli media. 5) revisi produk; (a) teknik pengumpulan data; (b) observasi; (c) angket; (d) dokumentasi. Kelayakan video animasi Rata-rata penilaian validator ahli materi mendapatkan presentase kelayakan sebesar $82,2 \%$ sehingga penilaian yang dicapai validator ahli materi mendapatkan kategori "Sangat Layak". Sedangkan rata-rata penilaian validator ahli media mendapatkan presentase kelayakan sebesar 79\%, sehingga penilaian yang dicapai dari validator ahli media mendapatkan kategori "Layak". Kemudian hasil rata-rata penilaian dari 5 guru masing-masing mendapat presentase kelayakan sebesar $88,4 \%, 85,6 \%, 82,8 \%, 85,6 \%$, dan $82,8 \%$ dengan rata-rata keseluruhan dari 5 guru keteria presentase kelayakan $85,04 \%$ dari persentase penilaian ke 5 guru mendapatkan kategori "Sangat Layak". Berdasarkan hasil uji validasi yang diperoleh maka video animasi layak digunakan dalam kegiatan pembelajaran konsep pola anak usia 5-6 tahun.
\end{abstract}

Kata Kunci :Video Animasi, Konsep Pola.

\footnotetext{
Abstract

This research was conducted to produce a product in the form of an animation video on knowledge of the concept of patterns of children aged 5-6 years. This type of research is research and development (Research and Development). The results of this research and development refer to the steps suggested by Sugiyono (2016); 1) potentials and problems. 2) data and information collection. 3) product design. 4) product validation; (a) expert

${ }^{1}$ Pendidikan Guru PAUD, Fakultas Ilmu Pendidikan, Universitas Negeri Riau

Alamat email eviatiriyana8@gmail.com

${ }^{2}$ Pendidikan Guru PAUD, Fakultas Ilmu Pendidikan, Universitas Negeri Riau Alamat email yeni.solfiah@lecturer.unri.ac.id

${ }^{3}$ Pendidikan Guru PAUD, Fakultas Ilmu Pendidikan, Universitas Negeri Riau Alamat email Daviqch@yahoo.com
} 
material test; (b) media expert test. 5) product revision; (a) data collection techniques; (b) observation; (c) questionnaire; (d) documentation. Feasibility of the animated video. The average evaluation of the material expert validator got a feasibility percentage of $82.2 \%$ so that the assessment achieved by the material expert validator got the "Very Appropriate" category. Meanwhile, the average media expert validator's assessment got a feasibility percentage of $79 \%$, so that the assessment achieved by the media expert validator got the "Eligible" category. Then the results of the average assessment of 5 teachers each got a feasibility percentage of $88.4 \%, 85.6 \%, 82.8 \%, 85.6 \%$, and $82.8 \%$ with an overall average of 5 teachers. the percentage of eligibility $85.04 \%$ of the percentage of the assessment of the 5 teachers got the category "Very Appropriate". Based on the results of the validation test obtained, the animated video is suitable for use in learning the concept of patterns for children aged 5-6 years.

Keywords: Animated Videos, Concept Patterns.

\section{PENDAHULUAN}

Anak Usia Dini adalah individu yang sedang mengalami proses pertumbuhan dan perkembangan yang sangat pesat, bahkan dikatakan sebagai lompatan perkembangan. Setiap anak di dunia memiliki berbagai kecerdasan dalam tingkat dan indikator yang berbeda-beda. Hal ini sesuai dengan karakteristik Kurikulum 2013 yaitu: "Mengoptimalkan perkembangan anak yang meliputi aspek nilai agama dan moral, fisik motorik, kognitif, bahasa, sosial emosional dan seni yang tercermin dalam keseimbangan kompetensi sikap, pengetahuan dan keterampilan".

Hadirnya teknologi pada media pendidikan juga dapat dirasakan pada jenjang Pendidikan Anak Usia Dini (PAUD). Karateristik anak usia dini bisa dikatakan memiliki keunikan sehingga berbeda satu sama lain, anak usia dini masuk dalam perkembangan berfikir pra oprasional kongkrit, begitu juga dalam menambah pengetahuannya anak mencari tahu dengan pengamatan secara langsung.

Dalam hal ini, upaya yang dapat dilakukan untuk meningkatkan pengetahuan konsep pola pada anak yaitu dengan menggunakan media pembelajaran.Dimana dalam ativitas pembelajaran, media dapat mendefenisikan sebagai sesuatu yang dapat membawa informasi dan pengetahuan dalam interaksi yang berlangsung antara pendidik dan anak didik Fathurrohman \& Sutikno (2010).

Peneliti memilih media pembelajaran video animasi untuk meningkatkan pengetahuan konsep pola, animasi merupakan satu bentuk presentasi bergambar yang paling menarik, yang berupa simulasi gambar bergerak yang menggambarkan perpindahan atau pergerakan suatu objek. Penggunaan animasi dalam proses pembelajaran sangat membantu dalam meningkatkan efektifitas dan efisiensi proses pengajaran, serta hasil pembelajaran yang meningkat Mayer (2009). Selain itu, penggunaan media pembelajaran khususnya animasi dapat meningkatkan daya tarik, serta motivasi peserta didik dalam mengikuti proses pembelajaran. Menurut Chilampikennel (2010) aturan pola dapat menggunakan benda, bentuk, dan warna.

Mengenal konsep pola dapat berkembang melalui penggunaan benda-benda nyata, gambar, desain tenun, simbol, dan gambar. Untuk mengembangkan pengetahuan peserta didik materi pembelajaran konsep pola, anak mengenali pola semenjak usia dini. Kemampuan untuk mengenali pola merupakan cara untuk anak dalam menemukan aturan pola dan mengikuti aturan dalam menyelesaikan polaPiaget \& Inhelder's (dalam Lestari, 2011). Adapun identifikasi masalah yang peneliti dapatkan dari observasi yakni;

1. Metode pembelajaran dalam penyampaian konsep pola masih menggunakan metode ceramah (storytelling) yang dirasa kurang tepat untuk menyampaikan materi pembelajaran. 
2. Media pembelajaran yang ada masih belum optimal untuk menunjang pengetahuan konsep pola.

3. Sarana yang tersedia belum bisa dimanfaatkan untuk menunjang pengetahuan konsep pola.

4. Belum adanya pengembangan animasi 2D sebagai media pembelajaran untuk menambah pengetahuan konsep pola.

Berdasarkan pengamatan penulis pada anak usia 5-6 tahun, dan aspek yang ingin dicapai oleh anak usia dini adalah mengenal konsep pola. Penulis melihat rata-rata pengetahuan anak dalam mengenal konsep pola masih rendah dan kemampuan anak dalam menyusun pola belum sesuai dengan tahap-tahap perkembangan yang seharusnya, hal ini dapat dilihat seperti: 1) Sebagian anak belum mampu mengklasifikasikan benda berdasarkan fungsi, bentuk atau warna dan ukuran, 2) Belum dapat menklasifikasikan benda ke dalam kelompok yang sama atau kelompok yan sejenis atau kelompok berpasangan yang lebih dari 2 variasi, 3) anak juga belum dapat mengenal pola $A B-A B$, $\mathrm{ABC}-\mathrm{ABC}$, dan $\mathrm{ABCD}-\mathrm{ABCD}$ dan mengulanginya.

Berdasarkan dari observasi tersebut, Pengembangan video animasi menjadi solusi dalam mengetahui pengetahuan konsep pola anak usia 5-6 tahun. Peneliti memandang perlu dilakukan Pengembangan Video Animasi Terhadap Pengetahuan Konsep PolaAnak Usia 5-6 Tahun.

\section{METODE PENELITIAN}

Jenis penelitian ini adalah penelitian dan pengembangan (Research and Development) dari Brog \& Gall (dalam Sugiono, 2013).Yang terdiri dari 7 tahapan tetapi dalam penelitian ini disederhanakan menjadi 5 tahapan dikarnakan adanya pendemi covid-19. Penelitian dilaksanakan hanya sampai tahap revisi produk berdasarkan saran dari validator. Validator dari penelitian ini terdiri dari ahli materi, ahli media dan ahli pendidik.

Instument pengumpulan data yang digunakan dalam penelitian pengembangan ini adalah angket untuk ahli materi, ahli media dan pendidik. Sedangkan teknik analisis data yang digunakan adalah dengan rumus.

$$
\frac{\overline{\mathrm{x}}=\sum_{\mathrm{i}}^{\mathrm{n}} \overline{\mathrm{x}}}{\mathrm{n}}
$$

Keterangan:

$$
\begin{aligned}
& \overline{\mathrm{X}}=\text { rata }- \text { rata penilaian dari para validator } \\
& \overline{\mathrm{x}} \mathrm{i}=\text { rata }- \text { rata skor hasil penilaian validatorke }-\mathrm{i} \\
& \mathrm{n}=\text { banyaknya validator }
\end{aligned}
$$

Dengan:

$$
\overline{\mathrm{x}} \mathrm{i}=\frac{\text { Jumlah Skor }}{\text { Skor maksimal }} \times 100
$$

Skala ukur penelitian pengembangan yang telah dimodivikasi dari Ridwan (2012). Untuk keperluan analisis kuantitatif, maka jawaban itu dapat diberi skor tabel berikut:

\begin{tabular}{ccc}
\multicolumn{3}{c}{ Skala Likert } \\
\hline No & Analisis Kuantitatif & Skor \\
\hline 1 & Sangat Menarik & 5 \\
2 & Menarik & 4 \\
3 & Cukup Menarik & 3 \\
\hline
\end{tabular}




\begin{tabular}{ccc}
\hline 4 & Tidak Menarik & 2 \\
5 & Sangat Tidak Menarik & 1 \\
\hline
\end{tabular}

Sumber: Riduwan (2012)

Hasil dari skor penilaian tersebut kemudian dicari rata-ratanya dari sejumlah subjek sampel uji coba dan dikonversikan kepernyataan penilaian untuk menentukan kualitas yang dihasilkan dari pendapat validator.

Kriteria Kelayakan

\begin{tabular}{cc}
\hline Skor persentase (\%) & Interpretasi \\
\hline $\mathrm{p}>80 \%$ & Sangat layak \\
$61 \%<\mathrm{P} \leq 80 \%$ & Layak \\
$41 \%<\mathrm{P} \leq 60 \%$ & Cukup layak \\
$20 \%<\mathrm{P} \leq 40 \%$ & Kurang layak \\
$\mathrm{P} \leq 20 \%$ & Sangat kurang layak \\
\hline Sumber: Ridwan (2012) &
\end{tabular}

\section{HASIL DAN PEMBAHASAN}

Media merupakan alat komunikasi yang berguna untuk mengefektifkan informasi yang disampaikan.Sebelum membuat media pembelajaran kita harus membuat rancangan atau desain. Adapun rancangan atau desain media video animasi konsep pola $A B-A B$, $\mathrm{ABC}-\mathrm{ABC}$, dan ABCD-ABCD dilakukan dengan beberapa tahapan yaitu; (1) Pembuatan isi materi video animasi; (2) Membuat rancangan atau desain sebagai berikut.

\section{Uji Kelayakan Ahli Materi, Media dan Pendidik}

Adapun hasil validasi produk oleh ahli sebagai berikut:

Tabel 1

Hasil Penilaian Validasi Ahli Materi

\begin{tabular}{|c|c|c|c|c|}
\hline $\begin{array}{l}\text { Indikator } \\
\text { penilaian }\end{array}$ & Indikator & Skor & $\begin{array}{c}\text { Rata-rata } \\
\text { skor }\end{array}$ & Persentase \\
\hline \multirow{9}{*}{ Materi } & 1. Kesesuian KI dengan KD & 4 & 4,11 & $82,2 \%$ \\
\hline & $\begin{array}{l}\text { 2. Kesesuaian } \\
\text { indikator }\end{array}$ & 4 & & \\
\hline & $\begin{array}{l}\text { 3. Kesesuaian materi dengan } \\
\text { kegiatan pembelajaran konsep } \\
\text { pola }\end{array}$ & 5 & & \\
\hline & $\begin{array}{l}\text { 4. Kesesuaian materi dengan } \\
\text { video animasi menganyam }\end{array}$ & 4 & & \\
\hline & $\begin{array}{l}\text { 5. Ketepatan tata bahasa yang } \\
\text { digunakan }\end{array}$ & 4 & & \\
\hline & $\begin{array}{lr}\text { 6. } & \begin{array}{l}\text { Kejelasan } \\
\text { memperagakan } \\
\text { menganyam }\end{array} \\
\text { cara }\end{array}$ & 4 & & \\
\hline & $\begin{array}{l}\text { 7. Melatih kemampuan fisik } \\
\text { motorik anak usia dini }\end{array}$ & 4 & & \\
\hline & $\begin{array}{l}\text { 8. Melatih kemampuan kognitif } \\
\text { anak usia dini }\end{array}$ & 4 & & \\
\hline & $\begin{array}{l}\text { 9. Melatih kemampuan sosial } \\
\text { emosional anak usia dini }\end{array}$ & 4 & & \\
\hline
\end{tabular}




\begin{tabular}{cccc} 
Total & 37 & 4,11 & $82,2 \%$ \\
Rerata skor & 4,11 & \multicolumn{3}{c}{ Sangat layak } \\
Kesimpulan & \multicolumn{3}{c}{ Sang } \\
\hline
\end{tabular}

Berdasarkan tabel penilaian oleh ahli materi di atas diketahui pada tentang materi mendapat presentase kelayakan 82,2\% dengan kategori "sangat Layak". Jumlah skor penilaian 37 dari 9 indikator penilaian. Rata-rata penilaian validator ahli materi yaitu 4,11 .

Tabel 2

Hasil Penilaian Validasi Ahli Media

\begin{tabular}{|c|c|c|c|c|}
\hline $\begin{array}{l}\text { Indikator } \\
\text { Penilaian } \\
\end{array}$ & Materi & Skor & $\begin{array}{c}\text { Rata-rata } \\
\text { peraspek }\end{array}$ & Persentase \\
\hline \multirow[t]{3}{*}{$\begin{array}{l}\text { Tampilan cover } \\
\text { video animasi }\end{array}$} & $\begin{array}{l}\text { 1. Judul video animasi } \\
\text { mewakili keseluruhan } \\
\text { isi video animasi }\end{array}$ & 4 & 4 & $80 \%$ \\
\hline & $\begin{array}{l}\text { 2. Judul video animasi } \\
\text { dapat menarik belajar } \\
\text { peserta didik }\end{array}$ & 4 & & \\
\hline & $\begin{array}{l}\text { 3. Warna cover video } \\
\text { animasi dapat menarik } \\
\text { minat peserta didik }\end{array}$ & 4 & & \\
\hline \multirow[t]{7}{*}{ Isi video animasi } & $\begin{array}{l}\text { 1. Video animasi konsep } \\
\text { pola dapat memberi } \\
\text { dampak positif bagi } \\
\text { peserta didik }\end{array}$ & 4 & 3,85 & $77 \%$ \\
\hline & $\begin{array}{l}\text { 2. Video animasi dapat } \\
\text { membantu peserta } \\
\text { didik untuk lebih } \\
\text { mudah memahami } \\
\text { pembelajaran konsep } \\
\text { pola }\end{array}$ & 4 & & \\
\hline & $\begin{array}{l}\text { 3. Video animasi dapat } \\
\text { membantu peserta } \\
\text { didik untuk menambah } \\
\text { pengetahuan konsep } \\
\text { pola }\end{array}$ & 4 & & \\
\hline & $\begin{array}{l}\text { 4. Isi video animasi dapat } \\
\text { dipahami oleh semua } \\
\text { pihak }\end{array}$ & 4 & & \\
\hline & $\begin{array}{l}\text { 5. Isi video animasi } \\
\text { disampaikan dengan } \\
\text { terstruktur }\end{array}$ & 4 & & \\
\hline & $\begin{array}{l}\text { 6. Isi video animasi } \\
\text { menggunakan bahasa } \\
\text { yang jelas }\end{array}$ & 3 & & \\
\hline & $\begin{array}{lr}\text { 7. Pembelajaran } & \text { yang } \\
\text { disampaikan } & \text { dalam } \\
\text { video animasi } & \text { dapat } \\
\text { ditangkap } & \text { dengan } \\
\text { mudah oleh } & \text { peserta } \\
\text { didik } & \end{array}$ & 4 & & \\
\hline $\begin{array}{l}\text { Bentuk tampilan } \\
\text { video animasi }\end{array}$ & $\begin{array}{l}\text { 8. Video animasi dibuat } \\
\text { dengan gambar yang }\end{array}$ & 4 & 4 & $80 \%$ \\
\hline
\end{tabular}


menarik

9. Video animasi dibuat sesuai dengan pola anyaman

10. Video animasi yang ada ditampilan tidak bertumpuk dengan gambar

11. Tata letak potongan kertas anyaman sesuai dengan pola anyaman

12.Kesesuaian gambar dengan isi video animasi

13. Kesesuaian suara dengan gerakan video animasi

14. Menggunakan warna yang cerah untuk menarik peserta didik

Total

Rerata Skor

Keterangan
4

Berdasarkan tabel penilaian oleh ahli media diketahui pada aspek 1 tentang tampilan cover video animasi mendapat presentase kelayakan 80\%, pada aspek 2 tentang isi video animasi mendapat presentase kelayakan 77\%, pada aspek 3 tentang bentuk tampilan video animasi mendapat presentase kelayakan 80\%. Jumlah skor penilaian 67 dari 17 indikator penilaian. Rata-rata penilaian validator ahli media yaitu 3,94 dengan presentase kelayakan sebesar $79 \%$.

Tabel 3

Hasil Penilaian Validasi Pendidik

\begin{tabular}{cccrrrrr}
\hline Aspek & \multicolumn{4}{c}{ Persentase kelayakan } & & $\begin{array}{c}\text { Rata-rata } \\
\text { persentase }\end{array}$ & $\begin{array}{c}\text { Tingkat } \\
\text { kelayakan }\end{array}$ \\
\hline & $\mathrm{MS}$ & $\mathrm{M}$ & $\mathrm{S}$ & $\mathrm{W}$ & $\mathrm{E}$ & & \\
Materi & $\mathrm{LS}$ & 8 & 8 & 8 & 8 & $85,04 \%$ & $\begin{array}{c}\text { Sangat } \\
\text { layak }\end{array}$ \\
& $8,4 \%$ & $5,6 \%$ & $2,8 \%$ & $5,6 \%$ & $2,8 \%$ & & A \\
\hline
\end{tabular}

Berdasarkan penilaian dari validator oleh Guru TK dapat dilihat memiliki tingkat kelayakan yaitu sangat layak dengan persentase kelayakan 85,04\%. Adapun rincian validasi oleh ibu Maya Laksita Sadewi,S.Pd memperoleh rata-rata persentase 88,4\% dengan kategori penilaian "Sangat Layak", untuk hasil validasi ibu Murdirkah, S.Pd memperoleh rata-rata persentase $85,6 \%$ dengan kategori penilaian "Sangat Layak". Selanjutnya hasil rata-rata persentase oleh ibu Sukisni, S.Pd sebesar 82,8\% dengan kategori penilaian "sangat layak", untuk validasi oleh ibu Warnida, S.Pd terhadap produk yang dikembangkan memperoleh kategori penilaian "Sangat Layak" dengan rata-rata persentase $85,6 \%$ dan validasi oleh ibuElinda Azhar, S.Pd memperoleh rata-rata persentase $82,8 \%$ dengan kategori penilaian "Sangat Layak".

Penelitian dan pengembangan produk dilakukan dengan sebuah perencanaan tahap awal yang dilakukan adalah melihat potensi dan masalah yang ada. Diketahui bahwa ada beberapa permasalahan terkait dengan media pembelajaran yang digunakan di TK kecamatan pangkalan lesung yakni media yang digunakan dalam pembelajaran tidak 
menarik, dan tidak bervariasi sehingga anak tidak bersemangat dalam mengikuti pembelajaran, kemudian video animasi belum pernah di buat dan di gunakan sebagai media pembelajaran, analisis karakteristik peserta didik, anak yang mudah teralih perhatiannya, anak yang lebih menyukai hal-hal baru seperti video animasi dan hal yang baru dilingkungannya. Piaget (dalam Trianto, 2011) pada masa ini sifat egosentris pada anak semakin nyata, anak mulai memiliki perspektif yang berbeda dengan orang lain disekitar, orang tua menganggap periode ini sebagai masa sulit karena anak sulit diatur, suka membantah dan banyak bertanya.

Berdasarkan beberapa masalah yang telah dijelaskan diatas peneliti mencoba memberikan solusi untuk mengatasi masalah tersebut dengan mengembangkan sebuah produk.Pembuatan sebuah media tidak hanya sekedar membuat tetapi harus memiliki tujuan, media dikatakan baik ketika mampu memerikan respon dan antusias pada dalam proses pemebelajaran (dalam Putri Anggraini,2019) sehingga peneliti membuat produk video animasi sebagai solusi untuk mengetahui pengetahuan konsep pola anak usia 5-6 tahun.

Produk yang telah dibuat dan dikembangkan tersebut divalidasi oleh beberapa ahli dan guru TK. Validasi dilakukan oleh dua orang ahli yaitu ahli materi dan ahli media yang merupakan ahli pada bidangnya, dan lima orang guru taman kanak-kanak yang telah sertifikasi.

Pada validasi yang dilakukan oleh validator ahli materi dari prodi PG PAUD Universitas Riau yaitu bapak Drs. Zulkifli N., M.Pd melakukan penilaian.Kegiatan validasi pada validator ahli materi hanya melalui 1 tahap, aspek yang dinilai yakni materi. Hasil penilaian mendapatkan nilai rata-rata 4,11 dengan kriteria persentase kelayakan $82,2 \%$, berdasarkan Ridwan (2012) skor persentase tersebut termasuk ke dalam kategori "sangat layak". Hal ini sejalan dengan penelitian Reny Pramitha Dkk, yang menyimpulkan bahwa persentase penilaian materi $87 \%$ kategori sangat praktis.Sehingga Video animasi yang dikembangkan sudah layak untuk digunakan tanpa revisi, Adapun saran yang diberikan bukan pada video animasi akan tetapi pada instrumen penilaian untuk fokus terhadap konsep pola anak usia dini.

Pada validasi yang dilakukan oleh validator ahli media dari prodi PGPAUD Universitas Riau yaitu ibu Dr. Rita Kurnia, M.Ed melakukan penilaian dan memberikan saran terkait aspek media.Kegiatan validasi pada validator ahli media hanya melalui 1 tahap. Ada 3 aspek yang dinilai yakni tampilan cover, isi video animasi dan bentuk tampilan. Hasil penilaian mendapatkan nilai rata-rata 3,94dengan kriteria persentase kelayakan 79\%, berdasarkan Ridwan (2012) skor persentase tersebut termasuk ke dalam kategori“layak".Penelitian ini sejalan dengan Siti Aminah (2019) yang menyimpulkan bahwa persentase penilian validator ahli media mendapatkan skor $87,50 \%$ dengan kategori penilaian sangat layak.

Penelitian ini sejalan dengan Riswan Hafiq Fajri Romadhona (2017) yang menyimpulkan bahwa persentase penilaian validator media mendapatkan skor 3,50\% dengan kategori layak. Hasil penelitian ini juga sejalan dengan penelitian yang dilakukan oleh Hapsinah Siregar (2017) yang menyimpulkan bahwa media animasi dapat menciptakan suasana pembelajaran yang menyengkan bagi anak, dan melalui media animasi dapat mengembangkan pengetahuan anak, maka dapat disimpulkan bahwa video animasi layak untuk mengetahui pengetahuan anak usia 5-6 tahun tanpa ada revisi.

Penilaian ahli pendidik dilakukan oleh 5 guru TK yang telah sertifikasi, yaitu ibu Maya Laksita Sadewi, S.Pd, Murdirkah, S.Pd, Sukisni, S.Pd, Warnida, S.Pd dan ibu Elinda Azhar, S.Pd. Ada aspek yang dinilai oleh pendidik yakni dari segi materi, dan rata-rata keseluruhan dari ke 5 guru keteria prestase kelayakan 85,04\%, berdasarkan Ridwan (2012) skor persentase tersebut termasuk ke dalam kategori "sangat layak" Sehingga Video animasi yang dikembangkan sudah layak untuk digunakan tanpa revisi. Hasil respon guru menyatakan tertarik untuk menggunakan video animasi pembelajaran dalam pembelajaran dikelas. 
Hasil penelitian ini sejalan Setyawati Rahayu (2014), yaitu untuk membantu pengembangan kognitif, anak perlu dibekali dengan pengalaman belajar yang dirancang melalui kegiatan mengobservasi dan mendengarkan dengan tepat.Pengalaman belajar dirancang diharapkan dapat membangun pengetahuan anak tentang konsep-konsep dalam kehidupannya. Konsep yang dikembangkan khususnya dalam penelitian ini yaitu konsep dalam mengenal konsep pola $\mathrm{AB}-\mathrm{AB}, \mathrm{ABC}-\mathrm{ABC}$ dan $\mathrm{ABCD}-\mathrm{ABCD}$.

Hasil penelitian ini juga sejalan dengan penelitian yang dilakukan oleh Hapsinah Siregar (2017) dimana didalam penelitian media animasi dapat menciptakan suasana pembelajaran yang menyenangkan bagi anak, dan melalui media animasi dapat mengembangkan pengetahuan anak. Penggunaan media animasi dalam pembelajaran mampu memberikan stimulus kepada anak usia dini untuk lebih semangat belajar dan perhatiannya terfokus pada materi. Animasi mempunyai peranan tersendiri dalam bidang pendidikan khususnya untuk mengetahui pengetahuan konsep pola anak usia dini dan dapat meningkatkan kualitas proses belajar mengajar.

Hasil penelitian ini menunjukan bahwa pengembangan video animasi konsep pola layak digunakan sebagai media pembelajaran untuk mengetahui pengetahuan konsep pola anak usia 5-6 tahun, dan dapat digunakan dalam proses belajar mengajar materi tentang konsep pola anak usia dini.

\section{SIMPULAN}

Video animasi layak digunakan sebagai media pembelajaran untuk mengetahui pengetahuan konsep pola anak usia 5-6 tahun berdasarkan penilaian validator ahli materi, ahli media dan ahli pendidik.

Sesuai dengan kesimpulan hasil penelitian, maka dapat dikemukakan beberapa rekomendasi yaitu:

1. Bagi peneliti selanjutnya, diharapkan dapat mengembangkan video animasi sebagai media pembelajaran konsep pola yang lebih bervariasi lagi untuk meningkatkan pengetahuan konsep pola anak usia dini. Sehingga media pembelajaran yang digunakan untuk kegiatan bermain sambil belajar di TK dapat meningkatkan efektivitas pembelajaran.

2. Bagi pembaca dapat melakukan pengembangan lebih lanjut terhadap media pembelajaran terutama video animasi agar dapat dihasilkan produk yang inovatif untuk digunakan dalam pembelajaran.

3. Bagi guru dapat memanfaatkan atau menggunakan video animasi dalam proses pembelajaran sehingga meningkatkan pengetahuan konsep pola anak usia dini dan dapat berkembang secara optimal.

\section{DAFTAR PUSTAKA}

Abdus Salam. 2008. Manajemen Personalia (Manajemen Sumber Daya Manusia).Ghalia. Jakarta

Asmoro.2010.Animasi Kartun Dari Analog Sampai Digital.Indeks. Jakarta

Azhar Arsyad. 2002. Media Pembelajaran. PT. Raja Grafindo Persada. Jakarta

Chilampikennel. 2010. "Meningkatkan Kemampuan Mengenal Konsep Pola Melalui Bermain Konstruktif Dengan Media Balok Pada Anak Kelompok A Tk Guworejo 2 Karangmalang Sragen Tahun Ajaran 2014/2015”. Jurnal Jurusan Pendidikan Anak Usia Dini Fakultas Keguruandan Ilmu Pendidikan. Program Studi PG-PAUD Universitas Sebelas Maret. Surakarta

Chong, A. 2008.Digital Animation. AVA Publishing SA. Singapura

Dendy Sugono. 2008. Kamus Besar Bahasa Indonesia Edisi Keempat.Gramedia. Jakarta

Donsu.2017. "Analisis Pengaruh Tingkat Religiusitas, Pengetahuan Dan Lingkungan

Sosial Terhadap Minat Menabung Mahasiswa Di Bank Syariah Kota Malang (Studi kasus Pada Mahasiswa Banyuwangi Di Kota Malang”).Jurnal Pendidikan 
Anak Usia Dini. Prodi Manajemen Fakultas Ekonomi dan Bisnis Universitas Islam Malang. Malang

Gredler. 2011. "Membangun Pengetahuan Anak Usia Dini Melalui Permainan Kontruktif Berdasarkan Perspektif Teori Piaget”.Jurnal Caksana-Pendidikan Anak Usia Dini.Universitas Sari Mutiara Indonesia. Medan

Hapsinah Siregar, 2017. Penggunaan Media Animasi Untuk Meningkatkan Kemampuan Sosial Emosional Pada Anak Usia Dini 5-6 Tahun Di TA Al-Muttaqin. Skripsi.Universitas Islam Negeri Sumatera Utara

Hegarty. 2004. "Pengaruh Pemanfaatan Media Pembelajaran Film Animasi Terhadap Hasil Belajar". Jurnal Teknologi Pendidikan Dan Pembelajaran. Studi Eksperimen Pada Mata Pelajaran Ips Siswa Kelas VII SMPN 6 Banjarmasin. Kalimantan Selatan

Kamriantiramli.2011. Penerapan Media Vidio Dan Animasi Pada Materi Memvakum Dan Menggisi Refrigeran Terhadap Hasil Siswa.Journal of Mechanical Engineering Education. Dapertemen Pendidikan Teknik Mesin, FPTK UPI. Bandung

Lestari KW. 2011. Konsep Matematika untuk Anak Usia Dini. Direktorat Pembinaan Pendidikan Anak Usia Dini. Direktorat Jenderal Pendidikan Anak Usia Dini Nonformal dan Informal. Kementerian Pendidikan Nasional. Jakarta

Mayer, Richard E. 2009. Multimedia Learning Prinsip dan Aplikasi. Pustaka Pelajar. Yogyakarta

Mayer, R. E. \&Morena, R. 2005.Animations as an Aid to Multimedia Learning.Educational Psychology Review. Jakarta

Notoatmodjo. 2014. Ilmu Perilaku Kesehatan. Rineka Cipta. Jakarta

Pupuh Fathurrohman \& M. Sobry Sutikno. 2010. Strategi Belajar Mengajar. PT. Refika Aditama. Bandung

Redi Awal Maulana. 2002. Math Untuk Anak Usia Dini. IGI PD. Kab Sumedang. Jawa Barat

Rian. 2007. "Analisis Karya Seni Kerajinan Anyam Tali Kur Siswa Kelas X Madrasah Aliyah Negeri 1 Stabat Berdasarkan Teknik Bentukdan Warna”. GorgaJurnal Seni Rupa. Program Studi Pendidikan Seni Rupa Universitas Negeri Medan. Medan

Rosna. 2009. "Analisis Karya Seni Kerajinan Anyam Tali Kur Siswa Kelas X Madrasah Aliyah Negeri 1 Stabat Berdasarkan Teknik Bentukdan Warna”. Gorga Jurnal Seni Rupa. Program Studi Pendidikan Seni Rupa Universitas Negeri Medan. Medan

Sugiyono. 2013. Metode Penelitian Kuantitatif, kualitatif, dan R\&D. PT Alfabeta. Bandung

Sugiyono. 2017. Metode Penelitian Kuantitatif, kualitatif, dan R\&D. PT Alfabeta. Bandung

Riduwan.2012. Skala Pengukuran Variabel-Variabel Penelitian.Alfabeta. Bandung

Rusman. 2012. Model-Model Pembelajaran. PT Rajagrafindo Persada. Depok

Setyawati Rahayu. 2014. Upaya Meningkatkan Kemampuan Mengenal Pola ABCD$A B C D$ Melalui Praktek Langsung Di Kelompok B TK Pertiwi 54 Teruman Bantul.Skripsi. Yogyakarta

Sukiman.2012. Pengembangan Media Pembelajaran.PT. Pustaka Insan Mandani. Yogyakarta

Suwardi Endraswara. 2012. Budaya Spritual Sebagai Wahana Membentuk Karakter Bangsa. FBS Universitas Negeri Yogyakarta. Yogyakarta

Slamet Suyanto. 2005. Dasar-Dasar Pendidikan Anak Usia Dini. Hikayat Publishing. Yogyakarta 